\title{
STABILITY OF ANARCHIC SOCIETIES *
}

\author{
by \\ Jack Hirshleifer \\ University of California, Los Angeles
}
Working Paper Number 769
Department of Economics
University of California, Los Angeles
Bunche 2263
Los Angeles, CA 90095-1477
May 1997

"Prepared for The New Palgrave Dictionary of Economics and the Law 


\section{STABILITY OF ANARCHIC SOCIETIES}

Abstract

Anarchy, a system in which contenders maintain resource accumulations de facto though not de jure, is a fragile social order. It may dissolve into formless 'amorphy', or may be displaced either by a system of vertical (Hobbesian) or horizontal (Lockian) social regulation. As against the vertical hegemonic alternative, anarchy is sustainable only when there are strongly diminishing returns to fighting effort; the 'decisiveness' of fighting helps determine the equilibrium polarity (number of surviving contenders). As against the horizontal alternative, anarchy is sustained by various forces -among them kinship, reciprocation, strategy complementarities, and group selection - - promoting voluntary provision of cooperative acts as a public good. Social regulation, the punishment or incapacitation of potential offenders, is a second-order public good; its provision is dependent upon the same forces. Emergence from anarchy at one level of social aggregation may sharpen the anarchic struggle at higher levels. 


\section{STABILITY OF ANARCHIC SOCIETIES}

Anarchy, as defined here, is not chaos. Rather, it is a kind of spontaneous order, one in which competitors are able to establish and maintain control over resources without the support of third parties or external law. "Mine and thine" exist de facto, though not de jure.

Anarchic social systems range from the division of the globe among national states to, at the micro level, customary patterns of individual courtesy and manners. Not all environments are capable of sustaining an anarchic order. Anarchy can be displaced by other patterns of relationships.

Perhaps because the animal world is the domain of largely unconstrained struggles for existence, biologists are well ahead of the human behavioral science disciplines when it comes to describing and modelling the many forms that anarchic social arrangements might take. The discussion here will rely heavily upon some of these biological investigations.

One important distinction made in the biological literature is between competition for resources via 'scramble' versus 'interference' (Nicholson 1954). Scramble competition occurs when resources are so dispersed or fugitive as to make sequestration or accumulation uneconomic. In the open sea, fish do not attempt to defend territories or amass inventories of food. Scramble competition is not anarchy as defined here; it might instead be termed amorphy (absence of form). On the human level, Rousseau evidently had amorphy in mind when he described man in the 'state of nature' as:

...wandering up and down the forests, without industry, without speech, without home, an equal stranger to war and to all ties, neither standing in need of his fellow-creatures nor having any desire to hurt 
them.... (Rousseau 1755 [n.d.]: 230)

Anarchy in the sense employed here corresponds to interference competition, which occurs in environments that permit de facto control of resources. Land territories are the most notable instances of animal resource sequestering; other examples include elephant seal males who defend harems of females and ant colonies who enslave ants of other species.

Anarchic societies, animal or human, can either "break down" into chaotic amorphy or "break up" into a more organized social structure. The discussion that follows will contrast two types of "break up": anarchy might be succeeded by a vertical form of organization (hegemony) or a horizontal form (a more or less egalitarian system of social control). That is, by a Hobbesian or a Lockian "social contract".

In anarchic social systems two separate technologies are typically at work: a technology of production and a technology of appropriation. combat. and control (Hirshleifer 1995: 27-28). There are ways of tilling the land, and quite a different set of ways of capturing land and securing it against intruders. Production might be an isolated or a joint effort, can employ more of one type of resource or more of another, may aim at short-term or long-term returns. Appropriation might be open or covert, can be intrusive or merely defensive, may involve actual fighting or perhaps only armed threat. And of course the two processes interact. The greater the risk of appropriative takeover, the larger the likelihood that production will be distorted in the direction of defensibility at the expense of efficiency. 
I. ANARCHIC VIABILITY, HEGEMONIC TAKEOVER, AND POLARITY

The simple model that follows (based on Hirshleifer 1995) indicates how productive and appropriative activities interact to determine the viability of anarchy as against the "vertical" alternative of hegemonic takeover.

Assume $\mathrm{N}=2$ equally capable contenders. Each aims solely to maximize own-income. Neither benevolent nor malevolent preferences play a role, nor is there any desire for leisure or other non-income-generating activity. The anarchic system is viable when there is a stable equilibrium in which both rivals survive.

At any moment of time each contender $i=1,2$ divides its current resource holdings $R_{i}$ between productive effort $E_{i}$ (designed to extract income from resources currently controlled) versus appropriative or fighting effort $F_{i}$ (aimed at acquiring new resources at the expense of competitors, or repelling them as they attempt to do the same):

$$
R_{i}=E_{i}+F_{i}
$$

The aggregate resource base $R=R_{1}+R_{2}$ is assumed constant and independent of the parties' actions.

Let the corresponding "intensities" $e_{i}$ and $f_{i}$ be defined as:

$$
e_{i}=E_{i} / R_{i} \text { and } f_{i} \equiv F_{i} / R_{i}
$$

The $e_{i}$ and $f_{i}$ are the crucial decision variables on each side, subject of course to: 


$$
e_{i}+f_{i}=1
$$

Assuming steady-state conditions, each side makes an optimal once-andfor-all choice of $e_{i}$ and $f_{1}$. Choosing a higher productive intensity $e_{1}$ means that more income $Y_{i}$ can be generated from current resource holdings. On the other hand, choosing a higher appropriative intensity $f_{i}$ enhances the prospect of obtaining and retaining resources.

Side $i$ produces income $Y_{i}$ from currently held resources:

$$
Y_{i}=E_{i}^{h}=\left(e_{i} R_{i}\right)^{h}
$$

Production function

(If $\mathrm{h}>1$ there are increasing marginal returns to productive effort, and the opposite if $\mathrm{h}<1$. )

The chosen fighting efforts interact via a Contest Success Function (CSF) to determine the respective success fractions $p_{1}$ and $p_{2}$ (where of course $\left.p_{1}+p_{2}=1\right)$ :

$$
\mathrm{p}_{1} / \mathrm{p}_{2}=\left(\mathrm{F}_{1} / \mathrm{F}_{2}\right)^{\mathrm{m}}
$$
Contest Success Function (CSF)

or equivalently:

$$
P_{1}=F_{1}^{m} /\left(F_{1}^{m}+F_{2}^{m}\right) \text { and } p_{2}=F_{2}^{m} /\left(F_{1}{ }^{m}+F_{2}{ }^{m}\right)
$$

Finally, the success fractions determine the division of the society's aggregate resources: 


$$
R_{1}=P_{i} R
$$

Resource Partition Equation

The special form (5a) for the Contest Success Function follows Tullock (1980: 97-103). While other forms of the CSF are also of interest -- see, e.g., Hirshleifer (1989) -- this version captures the aspects of the conflict technology emphasized here. In particular, the success ratio $\mathrm{P}_{1} / \mathrm{P}_{2}$ is determined by the ratio of the appropriative efforts $\mathrm{F}_{1} / \mathrm{F}_{2}$ and (what plays a crucial role in the analysis) a decisiveness parameter $m>0$.

As illustrated in Figure 1, the higher is $\mathrm{m}$, the more responsive is side l's success fraction $p_{1}$ to changes in appropriative effort $F_{1}$. When $m$ is low there is little to be gained by being a little stronger than the enemy; with high $m$, it can make a huge difference.

[Figure 1 about here]

As an illustration, trench warfare is associated with a low decisiveness parameter $\mathrm{m}$. On the Western front in World War I, attacks with even very large force superiority rarely succeeded in doing more than move the front lines back a few miles. In contrast, force preponderance tends to be much more decisive in encounter battles like naval fleet actions. Superior fleets sweep the seas clear of inferior ones. Returning to the model, routine steps lead to:

(7) $\quad p_{1} / p_{2}=\left(f_{1} / f_{2}\right)^{m /(1-m)}$ Equilibrium success ratio

Equation (7) describes the logically required steady-state relationship between the chosen appropriative intensities $f_{i}$ and the equilibrium success ratio $P_{1} / P_{2}$, which in turn equals the equilibrium resource ratio $R_{1} / R_{2}$. It 
hegemonic takeover. Given this condition, by postulating a minimal level of income $\bar{y}$ required for survival it is possible to determine the equilibrium number $N$ of contenders that an anarchic environment can support (Hirshleifer 1995: 37-39). The higher are $m$ and $\bar{y}$, the smaller is the equilibrium "polarity" N.

As an historical illustration, in ancient Greece the multi-polar (large N) city-state system was brought to an end by technological improvements that made large-scale naval warfare, with its associated high decisiveness $m$, possible. By the time of the Peloponnesian War, city-states had to accept subordination either to Athens or Sparta. Although Sparta's hegemony (after her ultimate naval victory in 405 B.C.E.) was only temporary, the city-states were never able to reassert their autonomy. Apart from Alexander's short-lived empire, the next several centuries were characterized by an oligo-polar system of a few major powers. In this period, it appears, the decisiveness parameter $m$ was high enough to rule out multi-polarity but not high enough for effective control by a single hegemon. Only in 146 B.C.E., dating from the final destruction of Carthage, was Roman hegemony over the Mediterranean world achieved.

And the importance of the decisiveness factor is by no means limited to military struggles among states. Within a state, features of democratic constitutions like separation of powers and bills of rights reduce the decisiveness of majority supremacy, thereby tending to moderate the intensity of factional struggles. If the political system were winner-takeall, decisiveness $m$ would be very high and all politics would be a fight to the death. ("Constitutions that are observed and last for a long time are those that reduce the stakes of political battles." -. Przeworski 1991: 36.) 
will also be evident that, asymmetries between the players having been ruled out, in any interior equilibrium $f_{1}=f_{2}$ and consequently $p_{1}-p_{2}$.

Figure 2 illustrates that a stable interior equilibrium can exist only

for $m<1$. (As the decisiveness parameter $m$ approaches 1 , the curves approach a limiting step function such that $p_{1} / p_{2}=0$ for all $f_{1}<f_{2}$, jumping to $p_{1} / p_{2}=\infty$ when $f_{1}>f_{2}$.) If $m>1$ the fighting technology is, in a sense, characterized by increasing returns. Whichever side chooses the higher fighting intensity $f_{i}$ is going to end up controlling all the resources. Or, if the contenders choose the same $f_{i}$, the resources will eventually be monopolized by whichever side has initially higher $R_{1}$. The central conclusion is that when preponderance of fighting effort is excessively decisive, anarchy gives way to hegemonic conquest.

[Figure 2 about here]

The model leaves open, however, just what hegemonic takeover entails. At an extreme it might take the form of murderous extinction of the conquered, as occurs in some biological contexts and is not unknown in human history. But more usually the overlord finds actual extermination unfeasible or undesirable, and chooses instead to subordinate and exploit the losers within some kind of hierarchical system. (See, e.g., Tullock $1974 \mathrm{Ch}$. 3, Vehrencamp 1983, Usher 1992 Ch. 4, McGuire and Olson 1996.)

It is straightforward to extend the model to any number $N$ of anarchic contenders. The generalization of ( 7 ) can be written:

$p_{1}: p_{2}: \ldots: p_{N}=\left(f_{1}: f_{2}: \ldots: f_{N}\right)^{m /(1-m)}$

Once again, $m<1$ is necessary for stability, that is, to prevent 
II. QUALIFICATIONS AND LIMITATIONS

A number of other mechanisms also influence the stability of anarchic systems as against hegemonic takeover.

Internal unity/disunity: In the model above, each contending entity was taken to be a unified optimizing agent. But all human aggregations are riven by internal conflicts. Internal disunity almost always increases with size, and therefore tends to check any tendency toward hegemony.

Distance and other sources of diminishing returns in fighting: The Conflict Success Function (5) made no allowance for geography. There is always some erosion in projecting military power over distance (Boulding $1962 \mathrm{Ch} .4$, Blum and Dudley 1989, Findlay 1996). And of course not just mileage is involved but also difficulty of terrain and water or other barriers.

Organizational difficulties also increase with distance. These sources of diminishing returns help explain why even quite small states sometimes survive at the fringes of great empires.

Over the centuries, transportation and organizational improvements have diminished the geographic obstacles to the projection of military power, thus promoting the trend from the Middle Ages on toward consolidation of smaller political entities into larger nation-states.

Offense/defense advantage: Also omitted from the Conflict Success Function above was any consideration of the relative advantages of offense versus defense. Defensive advantage tends to stabilize anarchic systems, while offense advantage favors hegemonic takeover. (Cederman 1994 provides some 
suggestive "evolutionary" simulations.) The introduction of cannon in the 15th century brought an end to a long period of defensive dominance centered upon the castle-fortress. This shift toward offense dominance also contributed importantly to the absorption of formerly independent or semiindependent principalities into larger national states.

Alliances: Alliances on the other hand tend to counter the prospect of hegemonic conquest (Niou and Ordeshook 1989), a notable example being Britain's traditional policy of allying against the most powerful state on the European continent.

The costs of war and the benefits of peace: Looking toward the current day, these technological trends might appear to suggest the near-inevitability of hegemonic conquest. Ballistic missiles and nuclear explosives have made the transport of destructive power over distance far less costly than ever before. And intrinsic to the nature of these weapons is an enormous offensive advantage: it has become ever easier to destroy, harder to prevent destruction. Improvements in communication, computers and so forth have enhanced the ability to form and manage large organizations. Nevertheless, the anarchic system of more or less independent national states has managed to maintain itself. Perhaps the major explanation has been the perceived costs of war and benefits of peace. Fighting to achieve hegemonic status may have become relatively unprofitable, even for the victor. The growing geographical scope of markets and the enlarged advantages of international productive specialization have come to seem more promising than the benefits even of world empire. But a word of caution: similar optimistic readings of 
economic and social trends have proved mistaken in the past, notably in the decades preceding World War I (Blainey 1973 Ch. 2).

III. A DIGRESSION: POPULATION AND INCOME

At this point it will be useful to take a step back from recent trends, to consider instead the more impoverished social systems that have prevailed over much of human history.

Returning to the model of Section I, imagine that Malthusian pressures are tending to push anarchic per-capita incomes $Y_{1}$ down toward the critical income life-sustaining level $\bar{y}$. One "solution" is that war casualties may stabilize the anarchic system. Among the Enga of New Guinea (Meggitt 1977), within each tribe's territory population growth tends to reduce per-capita incomes over time. The choice becomes: capture more territory or starve. Yet, owing to low decisiveness $m$, the anarchic system is dynamically stable: no single tribe has been able to take over. War casualties .. up to quite recently, about 358 of males died in battle or of war wounds - - bring percapita incomes $Y_{i}$ back in line with the viability limit $\bar{y}$.

On the other hand, in an experiment with Norway rats Calhoun (1962) found that sudden severe overcrowding led to a breakdown into amorphy (in the terminology employed here). Even the strongest rats were no longer able to defend territories against overwhelming numbers of intruders. In short, while Malthusian population adjustments can sometimes stabilize anarchic social systems under resource pressure, changes may come too fast for this to occur. 
IV. EXTENT AND TYPES OF COOPERATION UNDER ANARCHY

A crucial influence favoring the viability of anarchy is that the absence of hegemonic or more egalitarian forms of social control does not preclude a considerable degree of cooperation.

First of all, some forms of anarchic cooperation occur simply because they are merely incidental to self-interested actions. If larger flock sizes reduce predator efficiency, an individual who joins a herd for selfprotection helps others as well. Or consider conventions. If everyone else is driving on the right, even in the absence of policing it would not make sense to deviate and drive on the left.

Such "incidental" cooperation can emerge in many ways; for illustrative purposes, only a few of the possibilities will be reviewed here. Table 1 shows several illustrative $2 \times 2$ payoff matrices. The Assurance Game (AG) might be interpreted as a situation with two competing conventions (a Pareto-superior convention yielding the 4,4 payoffs at upper left, and a less desirable convention yielding 2,2 payoffs at lower right). Assuming the parties choose simultaneously, each such convention is a Nash equilibrium in pure strategies; there is also a mixed-strategy solution in which each player chooses among the two options with 50 \% probability each, receiving mean payoff 2.5 . Battle of the Sexes (BOS) can also be interpreted as a situation with two conventions, but here one convention favors the Row and the other the Column player. Again there are purestrategy Nash equilibria at upper-left and lower-right as well as a 50:50 mixed-strategy equilibrium with average payoffs 2.5 each. In either case, although the theory does not predict which of them will be achieved, all the 
equilibria involve some mutual payoff improvement over the uncoordinated outcomes.

[Table 1 about here]

(Still higher degrees of cooperation may be achievable when the environment is better modelled in terms of a sequential-move protocol, as opposed to the simultaneous-move protocol described above. If one player, say Row, were to move first then -. using the subgame-perfect equilibrium concept - - in AG the ideal 4,4 payoffs would be achieved and in BOS the 4,3 outcome that is one of the Pareto-efficient solutions.)

Chicken (CH) represents an environment with less parallelism of interests. Here the pure-strategy Nash equilibria are asymmetrical, so the outcome that is best for one player (payoff 4) is rather poor (payoff 2) for the other. There is also a symmetrical mixed-strategy equilibrium, again with 50:50 probabilities and yielding payoffs of 2.5 each. So in Chicken as well, a degree of mutual advantage is achieved, at least in comparison with the worst possible 1,1 outcome.

The fourth matrix, Prisoners' Dilemma (PD), represents the most intractable environment of those tabulated. (Though, since Prisoners' Dilemma is not a constant-sum game, there is still some range of mutual advantage.) It might seem that the players ought to be able to coordinate on the Pareto-efficient 3,3 payoffs at upper left, but in the single-round game this is not achievable as a Nash equilibrium. For each player the more cooperative option (upper row and left-hand column) is strictly dominated by the less cooperative "defect" choice. The only Nash equilibrium, for both simultaneous-move and sequential-move protocols, is the inferior purestrategy outcome 2,2 at the lower right. 
So far only 'incidental' cooperation has been considered, in which the contenders were motivated by strict self-interest. Yet under anarchy influences may also be at work to temper the force of self-interest, leading to some harmonization of strategy choices even in such unyielding traps as Prisoners' Dilemma.

Kinship: The most obvious instance of non-self-interested behavior is parental sacrifice on behalf of offspring. The biological explanation is well-known. Even though the underlying genes may be completely selfish (Dawkins 1976), parents and children share genes. So helping one's offspring is, from the point of view of the genes, in large part self-help. The PD (adjusted) matrix in Table 1 illustrates this effect, where the payoffs of the ordinary PD matrix have been recalculated to reflect an assumption that the two actors share 508 of their genes. (Thus the 3,3 payoffs at upper-left become 4.5,4.5 - each player counts not only his own 3 , but adds in the opponent's 3 as worth 1.5 additional for himself.) The adjusted PD matrix is now qualitatively closer to the Assurance Game AG, with an enhanced likelihood of achieving a cooperative outcome.

Reciprocation: If a donor can rely upon the beneficiary to respond in kind (and in sufficient degree), the former may be induced to sacrifice immediate self-interest. Setting aside kinship, what will make a beneficiary respond in kind? One possibility is that the donor's first move might make it in the immediate self-interest of the beneficiary to behave cooperatively. incurring costs to set up attractive business premises, an entrepreneur might induce customers to come in and buy.) This is not what is ordinarily 
14

meant by reciprocative cooperation, which requires some sacrifice of immediate self-interest on both sides. The main explanation offered has been that a series of temporary two-sided sacrifices of self-interest may be justified by a continuing pattern of association, in effect constituting a "self-enforcing contract" (Telser 1980). The Folk Theorem tells us that in repeated games many equilibria -. including mutually cooperative ones -. may be possible even if the one-stage game is Prisoners' Dilemma.

The biological literature has placed rather undue emphasis upon a simple reciprocative strategy known as TIT FOR TAT (TFT) in the repeatedplay Prisoners' Dilemma. (A TFT player makes a cooperative move in the first round, and in each succeeding round mirrors the opponent's previous cooperative or defect choice.) While TFT came out ahead of several other strategies in certain contests and simulations (Axelrod and Hamilton 1981, Axelrod 1984), its success was dependent upon a number of special assumptions -- among them the specific list of opposing strategies considered. In fact, TIT FOR TAT does not do consistently better than simpler (and therefore presumably cheaper) strategies like ALWAYS DEFECT or ALWAYS COOPERATE. In addition, TIT FOR TAT is a hopelessly inferior strategy if the competition takes the form of an elimination contest rather than a round-robin tournament. More generally, an all-TFT outcome is essentially never an Evolutionarily Stable Solution (ESS) in the sense of Maynard Smith (1976). That is, a population in which everyone is playing TIT FOR TAT can be successfully invaded by a number of other strategies (Hirshleifer and Martinez Coll 1988).

TIT FOR TAT or reciprocative strategies generally might be strengthened by ability to detect an opponent's cooperate or defect move in time to 
permit synchronous rather than deferred response (Frank 1988: 59-63), even if this ability were purchased at positive cost. Another mechanism might be reputation: $A$ is less likely to cheat $B$ if his doing so can be observed by $C, D$, and E. Again, such assessment would involve a cost, and is subject to deception and trickery.

The main message, therefore, is that patterns of reciprocation can facilitate mutual accommodation in a number of carefully defined contexts, but the prospect of reciprocation is no panacea for cooperation failures under anarchy.

\section{Strategy complementarity:}

A degree of cooperation may be sustained not by universal adoption of a single strategy - - whether TIT FOR TAT or other .. but by the interplay of a co-evolved set of different strategies. Sea-urchins tend to devastate kelp beds, unless kept in check by a super-predator in the form of sea-otters. The trio of species is viable, where perhaps no separate pair could survive. More abstractly, some remarkable simulations by Lomborg (1996) indicate that co-evolving sets of complementary strategies typically arrive at far higher levels of cooperation in the repeated-play Prisoners' Dilemma than an allTIT FOR TAT population would have achieved. This result will not of course surprise economists familiar with the power of the division of labor (Smith 1776 [1937] Bk. I, Ch. I-III).

Group selection: Currently highly controversial among biologists is another force favoring cooperation, with a long intellectual history going back to Charles Darwin: 
When two tribes of primeval man, living in the same country, came into competition, if (other circumstances being equal) the one tribe included a great number of courageous, sympathetic and faithful members, ..., this tribe would succeed better and conquer the other. (Darwin [1871] n.d.: 498).

Darwin suggests here that the habit of cooperation, even where disadvantageous to the individual, might be evolutionarily viable owing to its impact upon the differential survival of groups. In terms of the PD matrix in Table 1 , a population whose members always choose the more cooperative strategy will in aggregate reap higher 3,3 payoffs and so tend to increase in numbers relative to more selfish populations earning only 2,2 .

Group selection has been the subject of intense debate in the evolutionary literature and associated social science discussions. In recent decades the standard view (Williams 1966) has been that of the two forces - individual selection favoring selfishness and group selection favoring unselfishness - - the former must dominate. The key argument has been that individuals within a population have shorter 'turnover times' (are differentially selected faster) than populations as a whole. So the internal within-group trend toward selfishness will proceed more rapidly than any collective between-group gain from the displacement of less unselfish populations.

Yet it is unwarranted to claim that the within-group trend must always outweigh the between-group advantage of cooperative behavior. Among other instances, the power of group selection is illustrated by self-sacrificial 
behavior among the social insects (E. O. Wilson 1971: 320-324) and colonial organisms (Tullock 1990). (While kinship and other influences may also be involved in these cases, they do not provide an entirely adequate explanation.) Group selection is favored by rapid and severe attrition of groups, a condition that very likely characterized primal mankind (Alexander 1979 Ch. 4). Early humans appear to have associated in relatively evanescent bands, punctuated by frequent exterminations. In recent years biological opinion has been swinging back toward assigning a substantial evolutionary role to group selection (D. S. Wilson and Sober 1994).

V. EMERGENCE FROM ANARCHY: A HORIZONTAL SOCIAL CONTRACT?

Given the many different influences that facilitate a considerable degree of cooperation even under anarchy, is government really needed? This normative issue will not be explicitly addressed here. Instead, the attempt will be to examine, in a positive way, how it is that additional cooperative possibilities are opened up by the emergence from anarchy, and what some of the limitations might be .

As has been seen, anarchy might be displaced either by vertical (Hobbesian) or horizontal (Lockian) social regulation. The movement from anarchy to vertical hegemony, despite the complications discussed in Section I, is relatively unproblematic. Crudely speaking, the strongest takes over -- if he can -- and, having done so, may provide subordinates with some return in the way of incentives (a vertical social contract). How a Lockian outcome might emerge, and what form a horizontal social contract might take, 
are more difficult issues.

In its most drastically elemental form, horizontal social regulation of behavior can be thought of as a triadic interaction. Each single encounter involves two "primary" actors $X$ and $Y$ and one "regulative" actor $Z$ - where, over time, individuals can expect to find themselves in the $X, Y$, and $Z$ roles with about equal frequencies. Thinking in terms of the single-round Prisoners' Dilemma as the underlying pattern (though this is only one of many possibilities), $X$ and $Y$ choose each time whether to cooperate or defect and $z$ chooses whether or not to exercise regulation.

What form will regulatory intervention take? The economist naturally thinks in terms of influencing the rational calculations of the primary actors by penalizing defectors. This might have the desired effect upon $X$ and $Y$, but what about $Z^{\prime}$ 's motivation? Inflicting punishment is typically costly. If primary cooperation in the $\mathrm{X}$ or $\mathrm{Y}$ roles is a public good, then undertaking a costly regulatory act in the $Z$ role can be regarded as providing a second-order public good (Oliver 1980, Heckathorn 1989). Such "moralistic aggression" (Trivers 1971: p. 49) runs into the same Prisoners' Dilemma logic: rational agents will tend to shirk.

A second kind of regulatory act has been emphasized in some sociological analyses: not ex-post punishment but ex-ante control (Heckathorn 1996: 253-254). Whereas the threat of punishment influences the incentives of the primary actors, control operates directly upon their opportunities. A regulator might control the primary actors by physical means like exile and imprisonment, or by psychological means like hypnotism and ethical indoctrination. (On the analog of hypnotism in animal contexts see Dawkins $1982 \mathrm{Ch}$. 4.) These two forms of regulation correspond to the 
traditional distinction between "deterrence" and "incapacitation" in the literature on the economics of crime (see, e.g., Ehrlich 1981).

Carrying out the deterrent threat of punishment is essentially always costly to the regulative actor $Z$, but control or incapacitation might be directly and immediately profitable. Prisoners can put to useful work. And even forms of incapacitation, like indoctrination to instill "social ethics", might be manipulative (i.e., directly profitable to the regulatory actor). Viewed this way, parents train their offspring in family loyalty only in order to promote the evolutionary success of the parents' lineage (Ghiselin 1974: 40; Dawkins 1982: 56-58). Similarly, Marxians allege, the upper classes use symbols like religion or nation to indoctrinate the proletariat into docile behavior benefiting their oppressors.

of course, not all forms of social influence that incapacitate potential non-cooperators are manipulative. The most effective way to preach a social ethic, it has been said, is to live by it - which means very often foregoing private advantage.

Setting aside as exceptional those instances where control may be selfinterestedly profitable, the puzzle remains. What limits shirking when it comes to providing the regulative behavior that characterizes emergence from anarchy? The answer is that the same forces - kinship, reciprocation, strategy complementarity, and group selection - that supported provision of first-order public goods under anarchy are also at work to make people willing to provide second-order public goods as well. We would expect, therefore, that emergence from anarchy is more likely for groups composed largely of kin than non-kin, and more likely to be found in groups where the same individuals encounter one another repeatedly so that reciprocation can 
take place. A horizontal social contract is also more likely where the environment offers more profitable scope for the division of labor (complementary sets of strategies), and where group selection (differential group attrition) is rapid and severe. Through the influence of all these forces, motivations supporting the voluntary provision of both first-order and second-order public goods have probably become instilled in the psychic endowment of the human species. Thus, as Adam Smith suggested, there are two aspects of "the moral sentiments":

How selfish soever man may be supposed, there are evidently some principles in his nature, which interest him in the fortune of others, and render their happiness necessary to him.

All men, even the most stupid and unthinking, abhor fraud, perfidy, and injustice, and delight to see them punished. (Smith 1759 [1976], $47,171$.

VI. A FINAL NOTE

Owing to closer kinship, better monitoring of shirkers, etc., the collective-action problem is more readily solved in small groups. But these small groups in turn come into anarchic competition at the group level. This of course provides a cascading motivation for unification one level higher up. The upshot is that, even if anarchy breaks up into organization on one level, anarchic conflict may be sharpened on another level. If the clans within a tribe agree on a social contract, peace among the clans may be only the prelude to more violent struggles against other tribes. 
Bibliography

Alexander, Richard D. 1979. Darwinism and Human Affairs. Seattle: University of Washington Press.

Axelrod, Robert. 1984. The evolution of cooperation. New York: Basic Books. Axelrod, Robert and William D. Hamilton. 1981. The evolution of cooperation. Science 211: 1390-1396.

Blainey, Geoffrey. 1973. The Causes of War. New York: The Free Press. Blum, Ulrich and Leonard Dudley. 1989. A spatial approach to structural change: The making of the French hexagon. Journal of Economic History 49: $657-676$.

Boulding, Kenneth E. Conflict and Defense. New York: Harper \& Brothers, 1962.

Calhoun, J. B. 1962. Population density and social pathology. Scientific American 206: 139-148.

Cederman, Lars-Erik. 1994. Emergent polarity: Analyzing state-formation and power politics. International Studies Quarterly 38: 501-533.

Darwin, Charles. [1871] n.d. The Descent of Man in Relation to Sex. In Charles Darwin, The Origin of Species and The Descent of Man. New York: Random House, The Modern Library.

Dawkins, Richard. 1976. The Selfish Gene. New York, NY: Oxford University Press.

Dawkins, Richard. 1982. The Extended Phenotype. Oxford: Oxford University Press.

de Waal, Frans. 1982. Chimpanzee Politics. New York, NY: Harper \& Row.

Ehrlich, Isaac. 1981. On the usefulness of controlling individuals: An economic analysis of rehabilitation, incapacitation, and deterrence. 
American Economic Review 71: $307-322$.

Findlay, Ronald. 1996. Towards a model of territorial expansion and the limits of empire. In The Political Economy of Conflict and Appropriation, ed. Michelle R. Garfinkel and Stergios Skaperdas. Cambridge: Cambridge University Press.

Frank, Robert H. 1988. Passions within Reason. New York: W. W. Norton \& Co.

Ghiselin, Michael T. 1974. The Economy of Nature and the Evolution of Sex. Berkeley: University of California Press.

Heckathorn, Douglas D. 1989. Collective action and the second-order freerider problem. Rationality and Society. 1: 78-100.

Heckathorn, Douglas D. 1996. The dynamics and dilemmas of collective action. American Sociological Review 61: 250-277.

Hirshleifer, Jack. 1989. Conflict and rent-seeking success functions:

Ratio vs. difference models of relative success. Public Choice 63: $101-112$.

Hirshleifer, Jack. 1995. Anarchy and its breakdown. Journal of Political Economy 103: $26-52$.

Hirshleifer, Jack and Juan Carlos Martinez Coll. 1988. What strategies can support the evolutionary emergence of cooperation? Journal of Conflict Resolution 32: $367-398$.

Lomborg, Bjorn. 1996. Nucleus and shield: The evolution of social structure in the iterated Prisoner's Dilemma. American Sociological Review 61: 278-307.

Maynard Smith, J. 1976. Evolution and the theory of games. American Scientist $64: 41-45$. 
McGuire, Martin C. and Mancur 0lson. 1996. The economics of autocracy and majority rule. Journal of Economic Literature 34: 72-96.

Meggitt, Mervyn. 1977. Blood is Their Argument. Palo Alto CA: Mayfield Publishing Co.

Nicholson, A.J. 1954. An outline of the dynamics of animal populations. Australian Journal of Zoology 2: $9-65$.

Niou, Emerson N.S. and Peter C. Ordeshook 1989. Stability in international systems and the costs of war. In Models of Strategic Choice in Politics, ed. Peter C. Ordeshook, Ann Arbor MI: Univ. of Michigan Press.

Oliver, Pamela E. 1980. Rewards and punishments as selective incentives for collective action: Theoretical investigations. American Sociological Review 85: $1356-1375$.

Przeworski, Adam. Democracy and the Market. Cambridge: Cambridge University Press 1991.

Rousseau, Jean Jacques. 1755. A Discourse on the Origin of Inequality. In The Social Contract and Discourses, tr. G.D.H. Cole. Everyman's Library. New York: E.P. Dutton and Co.

Smith, Adam. 1759 [1976]. The Theory of Moral Sentiments. Indianapolis: Liberty Classics.

Smith, Adam. 1776 [1937]. The Wealth of Nations. New York: Random House, The Modern Library.

Telser, L.G. 1980. A theory of self-enforcing agreements. Journal of Business 53: $27-44$.

Trivers, Robert. 1971. The evolution of reciprocal altruism. Quarterly Review of Biology 46: $35-56$. 
Tullock, Gordon. The Social Dilemma. Blacksburg VA: University Publications, 1974.

Tullock, Gordon. 1980. Efficient rent-seeking. In Toward a Theory of the Rent-seeking Society, ed. J. M. Buchanan, R.D. Tollison, and G. Tullock. College Station: Texas A\&M University Press, 1980.

Tullock, Gordon. 1990. The economics of (very) primitive societies. Journal of Social and Biological Structures 13: 151-162.

Usher, D. 1992. The Welfare Economics of Markets, Voting and Predation. Ann Arbor, MI: University of Michigan Press.

Vehrencamp, Sandra L. 1983. A model for the evolution of despotic versus egalitarian societies. Animal Behavior 31: 667-682.

Williams, George C. 1966. Adaptation and Natural Selection. Princeton, NJ: Princeton University Press.

Wilson, David Sloan and Elliott Sober. 1994. Reintroducing group selection to the human behavioral sciences. Behavioral and Brain Sciences 17: $585-608$.

Wilson, Edward 0. 1971. The Insect Societies. Cmabridge, MA: Harvard University Press. 
Table 1

SELECTED $2 \times 2$ PAYOFF MATRICES

Assurance Game (AG)

$4,4 \quad 1,3$

$3,1 \quad 2,2$

Battle of the Sexes (BOS)

$4,3 \quad 1,2$

$2,3 \quad 3,4$

Chicken ( $\mathrm{CH})$

$3,3 \quad 2,4$

$4,2 \quad 1,1$

Prisoners' Dilemma (PD)

$3,3 \quad 1,4$

$4,1 \quad 2,2$

PD (Adjusted)
$4.5,4.5$
$3,4.5$
$4.5,3$
3,3 
Figure 1

CONTEST SUCCESS FUNCTION (CSF)

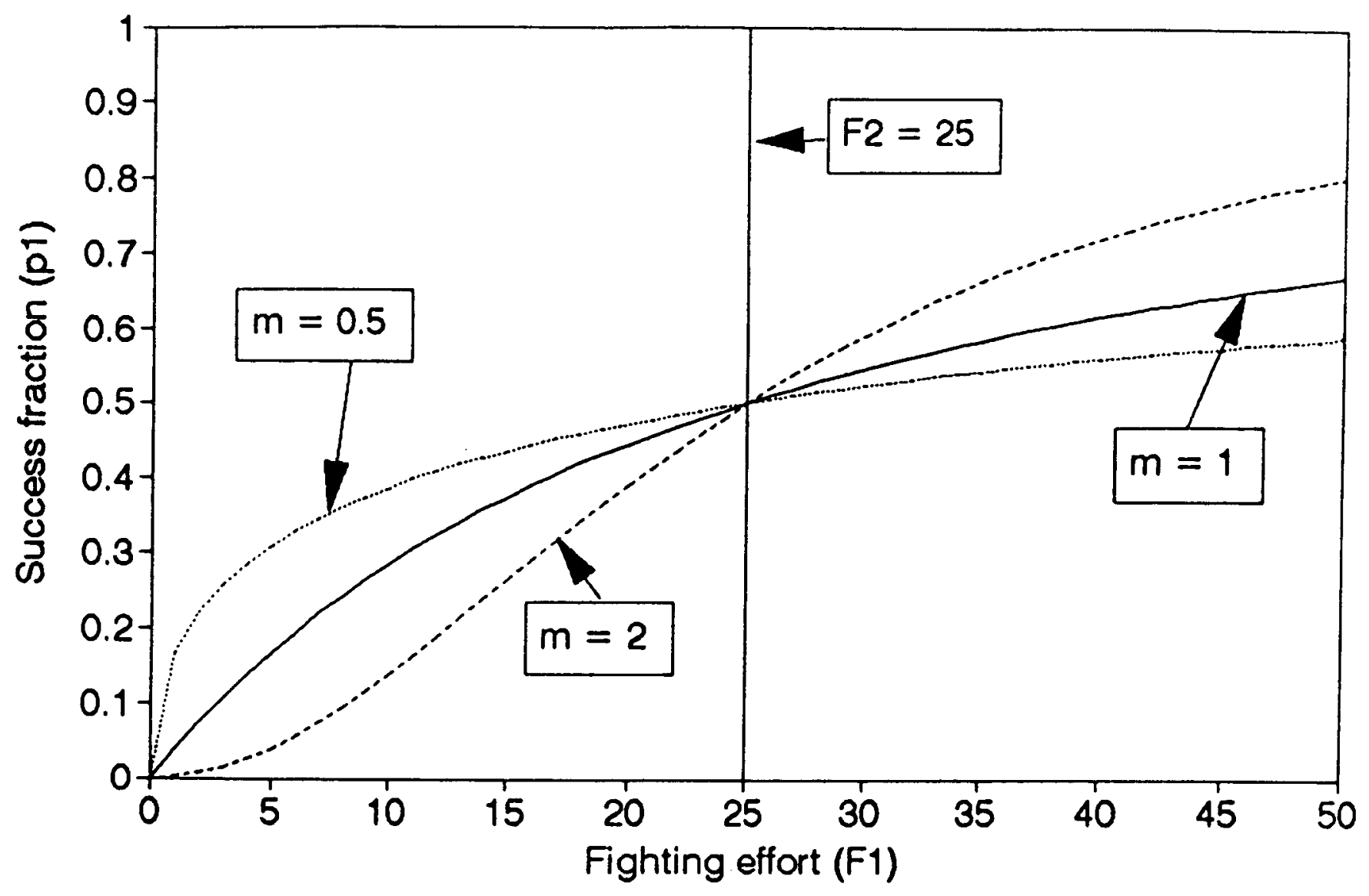


Figure 2

FIGHTING INTENSITIES AND SUCCESS RATIO

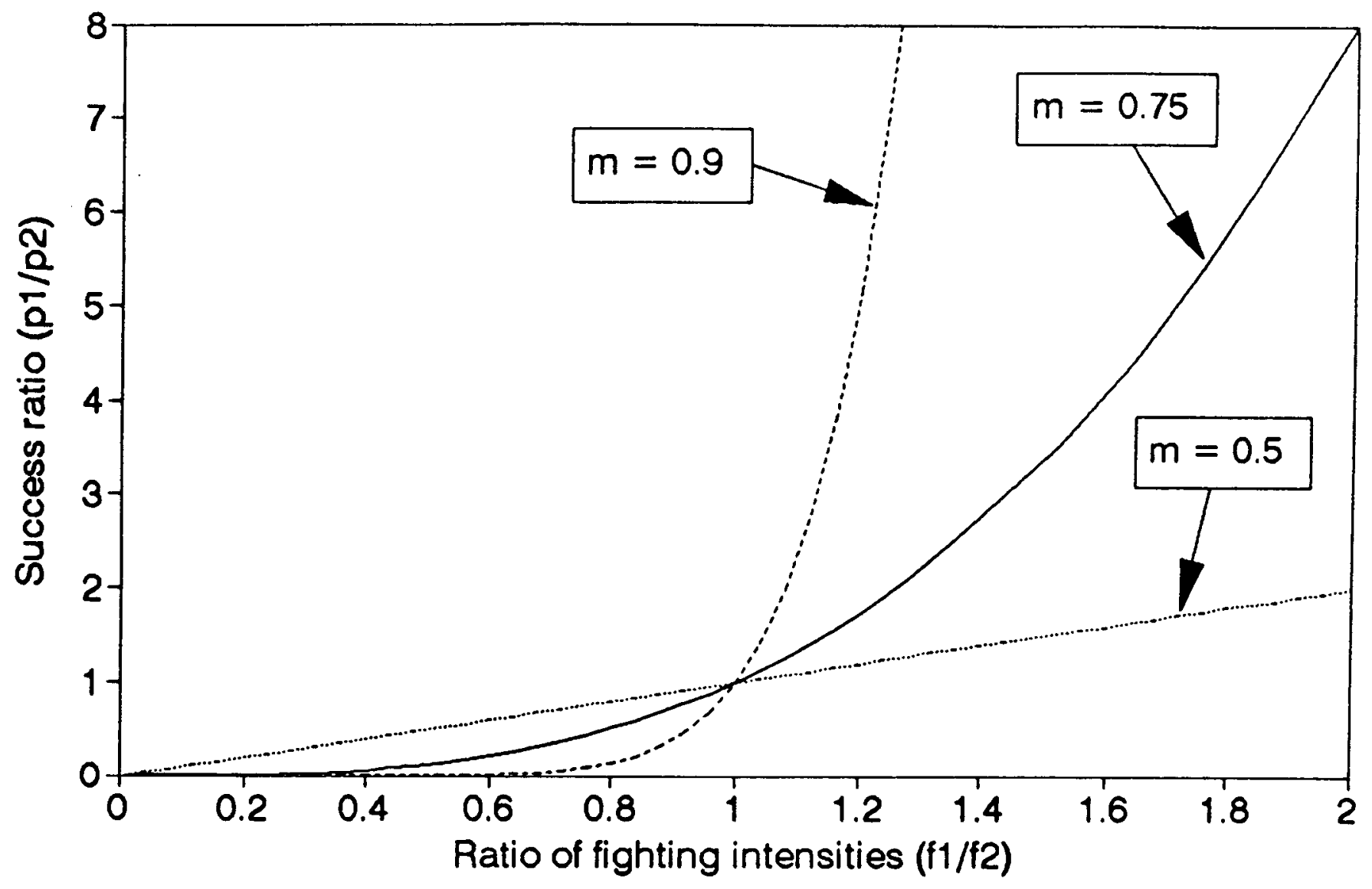

